\title{
THE SOCIAL AND CULTURAL IMPLICATIONS OF CURSE TABLETS [DEFIXIONES] IN BRITAIN AND ON THE CONTINENT
}

\author{
Geoff W. Adams
}

\begin{abstract}
The central theme of this study is to analyse the idiosyncratic nature of the Romano-British interpretation of the use of defixiones and various 'prayers for justice'. The prevalence of revenge as a theme within this comparatively isolated Roman province is notable and clearly illustrates the regional interpretation that affected the implementation of this religious tradition. The Romano-British curse tablets were largely reactionary, seeking either justice or revenge for a previous wrong, which in turn affected the motivation that led to their production. This regional interpretation was quite different to their overall use on the continent, but even these examples frequently also exhibit some degree of local interpretation by their issuers.
\end{abstract}

When approaching this topic, owing to the vast number of curse tablets and other religious inscriptions discovered throughout Europe there will naturally have to be some omissions from this discussion. The term defixio has enough problems in itself, with there being some debate concerning the formula and distinction in this term, ${ }^{1}$ which is why the title refers to other religious inscriptions. The nature of this discussion is to focus upon the social and cultural context of curse tablets, so there will be no discussion of the precise literary formulas used in these tablets. While discussing these curse tablets as a whole, I shall also have to limit the focus to two main temple precincts in Britain as well, namely being Bath and Uley. The purpose is to examine the curse tablets from these places within the wider social and cultural contexts in Europe, to attempt to find regional variations and uses for these tablets.

Firstly it is necessary to give a brief overview of the use and purpose of both Greek and Latin curse tablets throughout Europe, but for the present analysis more emphasis has been placed upon the Latin tablets. Curse tablets have been described as usually being "inscribed pieces of lead, usually in the form of small, thin sheets, intended to influence, by supernatural means, the actions or welfare of persons or animals against their will” 2 ; for example, a deity being requested to assist in the return of a stolen article. These tablets were usually discovered rolled into scrolls or folded into small packets, and were either deposited in tombs, sanctuaries or bodies of water. ${ }^{3}$ Owing to the debatable nature of this modern term, however, throughout this study they have simply been referred to as 'curse tablets' in order to avoid any confusion over specific terminology. These 'prayers for justice' seem to cover the negative aspects of religion, being used only when the individual has been hurt in some way, and desires retribution or compensation. Most religious inscriptional dedications, on the other hand, are associated with the positive aspect of religion, offering thanks or fulfilling a vow to a deity for a successful outcome to a request or

\footnotetext{
1 Versnel 1991a.

2 Jordan 1985a: 151.

${ }^{3}$ Jordan 1985b.
} 
attempting to gain personal favour with that deity. As Tomlin comments, these curse tablets were usually the "loser's last resort", to ensure the bad luck of someone else, or to correct one's own bad luck. ${ }^{4}$ The 'prayer for justice' was as much a quasi-legal as a religious contract, a petition for justice, while also being a magical incantation.

The tradition of writing curses on lead tablets appears to have originated in Greece, with the earliest examples having been discovered in Sicily, Olbia and Attica dated to the fifth century B.C., ${ }^{5}$ and by the second century AD they were being written throughout Western Europe, ${ }^{6}$ with this practice continuing throughout the Mediterranean until at least the sixth century A.D.7 Most Continental curse tablets discovered are 'binding' curses, ${ }^{8}$ which, according to Faraone, developed out of a special form of ritual that was primarily invoked by individuals who were in a "lopsided antagonistic situation, to bind the power of their opponents." 9 The use of magic in this fashion sought to balance out various circumstances beyond the sociopolitical realities that limited the options of the individual. ${ }^{10}$ The use of binding curses in Greece even extended from games to the law courts, such as in Athens, ${ }^{11}$ thus highlighting their flexible use by various social strata of the community, throughout many of the Greek States. ${ }^{12}$

Hecate, Demeter and Kore were common deities addressed in Greek curse tablets, probably because of their connection with the dominion of death and the underworld..$^{13}$ In another example discovered near the Agora in Athens, Hecate, Plouton, the Fates, Persephone and Hermes were all invoked to punish thieves and those having knowledge of the crime. ${ }^{14}$ In this example, it appears that the individual wanted to make absolutely sure that there would be retribution and was in no way limited by the number of deities addressed. It is also of interest to note that all of these deities had a connection with death and, in the mind of this person, it seems likely that they would have been appropriate deities for such magical vengeance. Several other examples of curse tablets have been included within this study, using several examples discovered near the Agora in Athens that are indicative of typical Greek curse tablets. In this instance there are nine curse tablets written in the same hand, and of these, six curse athletes running in the Panathenaia, whereas the other three are against men who visit prostitutes..$^{15}$ There are several other examples of sporting curses known, for example in Carthage four curses on charioteers and their horses have been discovered. ${ }^{16}$ Similar types of curses have also been discovered in Hadrumetum and Lepcis Magna. ${ }^{17}$ The most common type of curse is the 'binding

\footnotetext{
4 Tomlin 1988: 60.

${ }^{5}$ Faraone 1991a: 165. However, this practice of making binding curses may have originated in the Bronze Age. See Faraone 1996: 111-12.

${ }^{6}$ Faraone 1991b: 3.

${ }^{7}$ Jordan 1985a: 151.

${ }^{8}$ Fowler 1995: 3-4.

${ }^{9}$ Faraone 1991b: 20.

${ }^{10}$ Gordon 1987: 60.

${ }^{11}$ Faraone 1985: 150-4; Faraone 1999: 111-18.

12 See Jordan 2000: 5-35.

13 Versnel 1991a: 64.

${ }^{14}$ Jordan 1985a: 159, n. 21.

${ }^{15}$ Jordan 1985a: 160-1, n. 24-32.

${ }^{16}$ Jordan 1985a: 184-5, n. 138-141.

${ }^{17}$ Jordan 1985a: 185, 187, n. 144, 149.
} 
curse'. A good example of this style of curse tablet was discovered at Carystus on the island of Euboea, which reads:

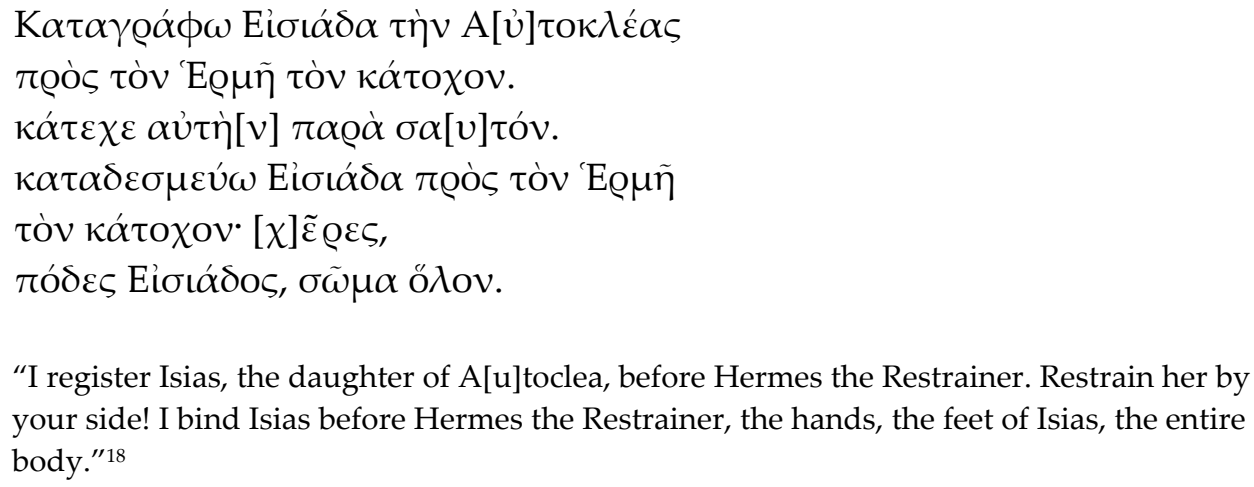

A good example of a Greek binding curse has also been discovered in Rome, where the folded lead tablet has a drawing of a smiling figure, whose torso is bound in cords and the head and shoulders are pierced with nails. If this isn't enough, a long snake is also drawn coiling around the figure, ready to strike. ${ }^{19}$ Another example of a binding curse tablet, discovered in Kyrenaika, requests Tyche, Zeus and the Charities to bind the tongue, hands, and the feet of the intended female victim. ${ }^{20}$ There are also several examples of curse tablets written by men in most cases, but not all, intended to make women fall in love with them, with several examples discovered in Egypt. ${ }^{21}$ Several of these were accompanied by so-called 'voodoo' dolls, which may have increased the potency of this incantation.

On the Continent, many of the Latin curse tablets followed a similar method. A good example of this was discovered in a pit in Rom, in modern France, dated to the early third century AD. It reads as follows:

$\begin{array}{ll}\text { Apeci alligato Tr[i]- } & \text { re voteat imol[a]- } \\ \text { nemeton Caticno- } & \text { re. Aqanno te tor- } \\ \text { n, nudato Seneciolu- } & \text { qeto. Nana te com- } \\ \text { m Asedem Trition } & \text { cruciato. Sosio de Eu- } \\ \text { Neocarinon Didon- } & \text { molpo mimo ne eni- } \\ \text { m(m). Sosio deliria } & \text { tuisse poteat. ebri- } \\ \text { Sosio pyra Sosio } & \text { a vi monam age- } \\ \text { cottidie doleto. } & \text { re neqeat }(i) \text { in eqo- } \\ \text { Sosio loqui nequeat. } & \text { leo. ne voteat imol- } \\ \text { Sosio de Maturo et Eri- } & \text { are. Sosio de Fotio m- } \\ \text { dunna ne cluisse, Sosio } & \text { imo ne adem }(t) i s s e \\ & \text { victoriam voteat...... } \\ & \text { v......... }\end{array}$

\footnotetext{
${ }^{18}$ Faraone 1991b: 3.

${ }^{19}$ Jordan 1985a: 182, n. 131.

${ }^{20}$ Jordan 1985a: 187, n. 150.

${ }^{21}$ Jordan 1985a: 188-9, n. 151-3, 155-6.
} 


\begin{abstract}
"Apecius, thou must bind Trinemetos and Caticnos. Thou must strip Seniciolus, Asedis, Tritios, Neocarinos, Dido. Sosio must (suffer) from delirium, Sosio must (suffer) from fever, Sosio must suffer pain every day, Sosio must be unable to speak, Sosio must not triumph (?) over Maturus and Eridunna, Sosio must not be able to sacrifice. Aquanno must torment thee. Nane must torture thee. Sosio must never do better than the mime Eumolpos. He must never be capable of lifting the woman onto the horse with inebriated force.(?) He must not be able to sacrifice. Sosio must not be able to surpass the mime Fotios...."22
\end{abstract}

These curse tablets have been defined by Versnel as 'judicial prayers', and it is the case that these examples are not typical of Greek defixiones. As noted in the Greek curse tablets, there appears to be no limits on the specific subject matter for the individual to seek their downfall through such an incantation, such as the people involved with the theatre, for example Sosio, Eumolpos and Fotios being mimes. One of the most interesting aspects of this curse is the phrase 'He must not be able to sacrifice', which as Versnel has previously noted, would imply that by having unsuccessful sacrifices, the wishes of the person would not be granted. ${ }^{23}$ Another example, which was discovered in Corsica, reads as follows:
[---] ule vindica te. Qui tibi male flaciet], qui [---]
[---v]indica te et si C. Statius tibi nocuit, ab eo vind[ica te---]
[---persequa?]ris eum, ut male contabescat usque dum morie[t]ur---
cumque alis, et si Pollio conscius est et illum persequaris, ni annum ducat.

\begin{abstract}
"------ule (probably the name of the god), avenge yourself. Whoever has done you harm.......avenge yourself on him, and if C. Statius has injured you, avenge yourself on him [....persecute] him in order that he may waste away horribly until he dies. And whoever else - for instance, if Pollio - is an accomplice, persecute him as well, so that he won't live out the year." 24
\end{abstract}

One of the most interesting aspects which is shown in this example, is that the offence is not against the individual writing the curse, but instead it is directly against the god. It appears that by writing this curse tablet it seems to pass the disgrace straight to the god being approached and it becomes their responsibility to obtain justice for whatever offence has occurred. The types of offences that provoked the writing of such curses were diverse, where it appears, almost anything justified such incantations..$^{25}$ It is at this point the focus must turn to a discussion of theft in curse tablets, particularly those discovered at the Bath and Uley temple precincts.

But firstly, there are also a small number of Continental Greek and Latin curse tablets concerned with theft which have been discovered. It is not common for Greek curse tablets to be so focused upon matters of theft, with there being only fourteen examples known throughout the Continent. A good example is a Greek curse tablet has been discovered on the Island of Delos, which reads as follows:

\footnotetext{
22 Versnel 1985: 247-8.

23 Versnel 1985: 263.

${ }^{24}$ Versnel 1991a: 82.

${ }^{25}$ Tomlin 1988: 60.
} 
Side A:

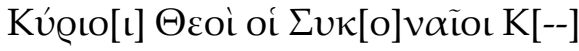 \\ $[$ K]v@í[ $\alpha] \Theta \varepsilon[\dot{\alpha}] \Sigma v e i ́ \alpha \hat{\eta} \Sigma v \kappa o v \alpha \Sigma[--]$

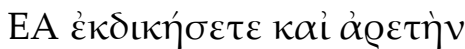 \\ $\gamma \varepsilon v \nu \eta ́ \sigma \varepsilon \tau \varepsilon \kappa \varepsilon \dot{~ \delta ı O \gamma ı ́ ́ \sigma \varepsilon \tau \varepsilon ~}$

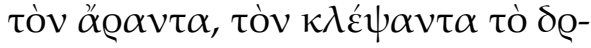

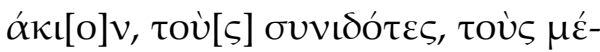

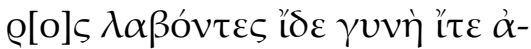 \\ vท́อ.
}

Lords gods Sykonaioi, Lady goddess Syria Sykona, punish and give expression to your wondrous power and direct your anger to the one who took away my necklace, who stole it, those who had knowledge of it and those who were accomplices, whether man or woman.

Side B:

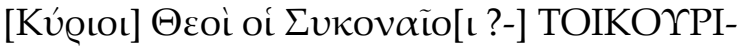

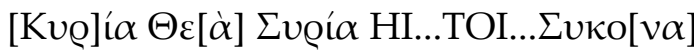
$[\dot{\varepsilon} \kappa \delta \iota \kappa] \eta ́ \sigma \varepsilon \tau \varepsilon \kappa \dot{\varepsilon}[\dot{\alpha}] \varrho \varepsilon \tau \eta \dot{\nu} \gamma \varepsilon v[\nu] \eta \dot{\sigma \varepsilon \tau \varepsilon}$.

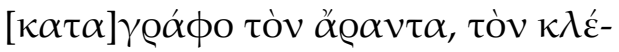

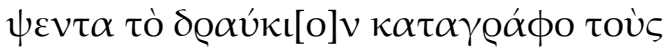

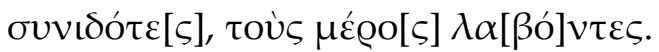

Lords gods Sykonaioi...., Lady goddess Syria.... Sykonna, punish, and give expression to
your wondrous power. I curse the one who took away, who stole, my necklace. I curse
those who had knowledge of it, those who participated.26

Side B is similar in its emphasis to Side A, except it is a little more specific, with a curse on the thief's brain, soul, muscles and hands following this passage, and also by a curse which covers the wrong-doer from his head to his toenails. ${ }^{27}$ This style of cursing seems to have been quite prevalent, with the devotee choosing specific parts of the body to be cursed by the chosen deity, and if all else fails, simply cursing their entire body. Another example of this has been discovered in Athens, which addresses Hecate directly to "cut out the heart of the thieves or thief" who stole some articles of clothing. ${ }^{28}$ Excavations at Cnidus in Asia Minor revealed another curse tablet discovered in the Temple of Demeter, which again deals with the loss or theft of clothing. The text reads as follows: ${ }^{29}$

\footnotetext{
${ }^{26}$ Versnel 1991a: 66-7.

27 Jordan 1985a: 168, n. 58.

${ }^{28}$ Versnel 1991a: 66.

${ }^{29}$ Audollent 1967 [= 1904]: 8.
} 


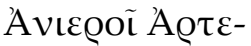 \\ $\mu \varepsilon i \varsigma \Delta \alpha ́ \mu \alpha \tau \varrho \iota$ \\ Koú@ $\alpha[\iota \theta \varepsilon o] \tilde{i} \varsigma \pi \alpha-$

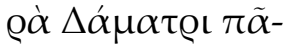

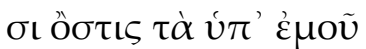 \\ $\kappa \alpha \tau \alpha \lambda \iota \phi \theta \varepsilon \dot{v} \tau \tau \alpha$ i-

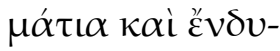 \\ $\mu \alpha \kappa \alpha \grave{\alpha} \alpha \dot{\alpha} \kappa \omega[\lambda-]$

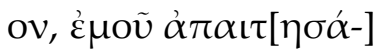

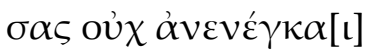

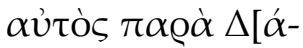

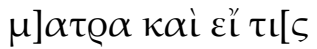

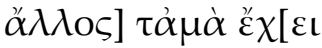

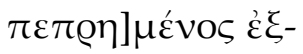

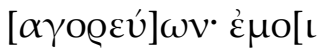

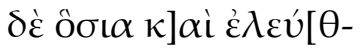

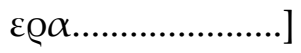 \\ $\kappa \alpha \grave{i} \sigma v \mu \pi เ \varepsilon \tilde{\imath} v \kappa \alpha \grave{i}$ \\ $\sigma v \mu \phi \alpha \gamma \varepsilon \tilde{\mathrm{i} v} \kappa \alpha i$

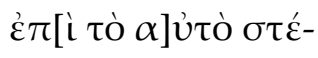 \\ $\gamma \mathrm{O} \dot{\varepsilon}[\lambda \theta] \varepsilon \tilde{\varepsilon} v^{*} \alpha \dot{\alpha} \delta i_{-}$ \\ $\kappa \eta \mu \alpha \iota ~ \gamma \dot{\alpha} \varrho \Delta \varepsilon \dot{\varepsilon} \sigma \pi \mathrm{L}[\mathrm{l}]$ \\ $v \alpha \Delta \alpha ́ \mu \alpha \tau \varepsilon \rho$.
}

\begin{abstract}
Artemis 'dedicates' to Demeter and Kore and all the gods with Demeter, the person who would return to me the articles of clothing, the cloak and the stole, that I left behind, although I have asked for them back. let him bring them in person to Demeter even if it is someone else who has my possessions, let him burn, and let him publicly confess his guilt. But may I be free and innocent of any offence against religion....if I drink and eat with him and come under the same roof with him. For I have been wronged, Mistress Demeter. ${ }^{30}$
\end{abstract}

Throughout the continent, there are only six known Latin tablets concerned with theft. ${ }^{31}$ A good example of these has been discovered at Wilten-Veldidena, which reads:

Side A

Secundina Mecurio et

Moltino mandat, ut siquis * XIIII sive draucus duos sustulit, ut eum sive fortunas eius infidus Cacus sic auferat quomodi ill(a)e ablatum est id quod vobis delegat, ut persecuatis vobisque deligat, $u t$
Side B

persicuatis et eum

aversum a fortunis(s)uis avertatis et a suis proxsimis et ab eis quos carissimos abeat, oc vobis mandat, vos [e]um cor[ipi]atis.

\footnotetext{
30 Versnel 1991a: 72.

31 Tomlin 1988: 62.
} 


\begin{abstract}
"Secundina charges Mecurius and Moltinus that whoever has stolen 14 denarii or two necklaces, that the perfidious Cacus take him away or his possessions, just as they (her possessions) have been taken away from her, the very things that she transfers to you to track down. And she also assigns you to persecute him and separate him from his possessions and from his fellow men and from those who are dearest to him. With that she charges you; you have to catch him." 32
\end{abstract}

But the largest numbers of tablets that deal with theft offences have been discovered in Britain. ${ }^{33}$ The majority of the Romano-British tablets have been discovered at Bath and Uley, two very important religious sites. The two most common deities that are appealed to are Sulis-Minerva at Bath, and Mercury at Uley, with a few tablets to other deities, such as Mars or Nodens. ${ }^{34}$ A unique feature of the curse tablets from Roman Britain is that they, for the most part, deal solely with matters of theft, which is most uncommon in comparison to elsewhere in the Greco-Roman world. ${ }^{35}$ There have been only four other curse tablets discovered in Britain not dealing with theft; one concerned with love, ${ }^{36}$ and three connected with perjury. ${ }^{37}$

In regard to the tablets found at Bath, most of the articles that have been stolen are portable items, and few items mentioned were of very much worth: such as clothing, mainly outer garments, a few coins and some rings. ${ }^{38}$ Tablet $5^{39}$ is a good example, with the restored text reading:

\author{
[D]ocimedis \\ [p]erdidi(t) mani- \\ cilia dua qui \\ illas involavi(t) \\ ut mentes sua(s) \\ perd[at] et \\ oculos su[o]s \\ in fano ubi \\ destina $(t)$
}

"Docimedis has lost two gloves. (He asks) that (the person) who has stolen them should lose his minds [sic] and his eyes in the temple where (she) appoints." 40

The vengeance requested for the loss of items seems quite drastic on occasion. On Tablet 45, Sulis is requested by the devotee to curse the thief with blindness and childlessness until the stolen article is returned to the temple. ${ }^{41}$ Another good example has been transcribed to read:

\footnotetext{
32 Versnel 1991a: 83.

${ }^{33}$ Reynolds 1990: 381-2.

${ }^{34}$ Woodward \& Leach 1993: 115, and for defixio dedicated to Nodens see RIB 306.

${ }^{35}$ Adams 2005: 68.

${ }^{36}$ Hassall \& Tomlin 1986: 428-31.

${ }^{37}$ RIB 6,7,221.

38 Tomlin 1988: 79.

${ }^{39}$ The tablet numbers referred to in reference to the Bath defixiones are taken from Tomlin 1988.

40 Tomlin 1988: 114, n. 5.

${ }^{41}$ Tomlin 1988: 166, n. 45.
} 


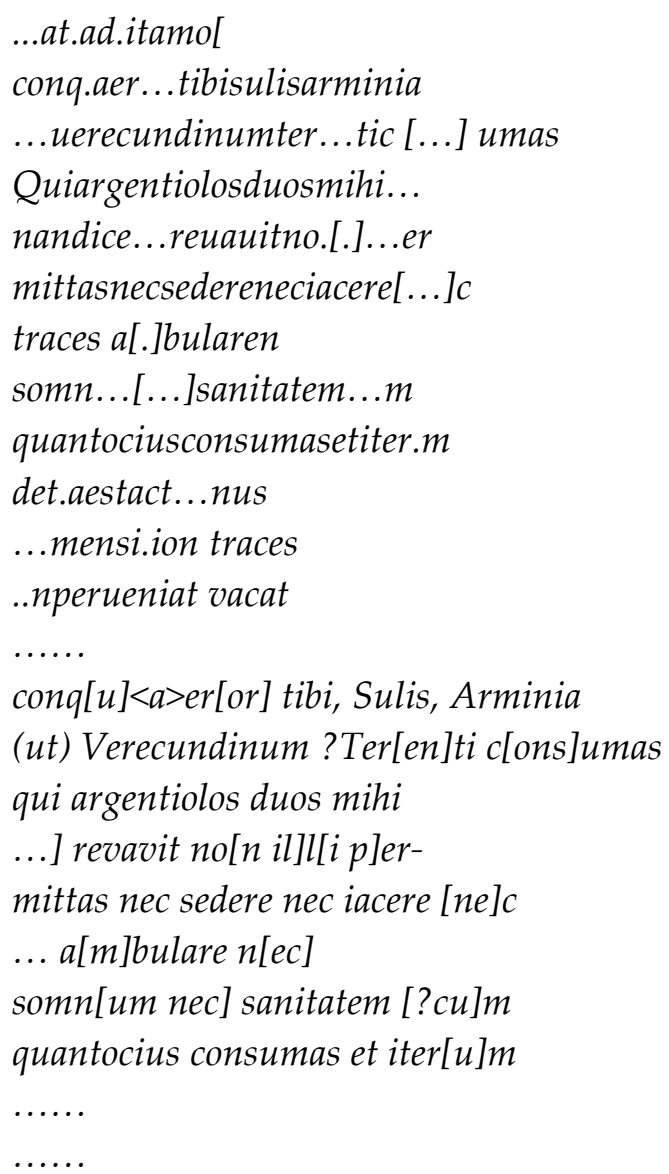

There are several tablets which request that the thief should not be able to pay back the debt of this wrong in any way than 'with their own blood', which again stresses the obvious malevolence felt by many of the cursers, but it still seems less uncomfortable than the thief in Tablet 62 who was meant to produce a cloak, tunic and horse blanket from their nose within nine days.

The style of Latin used on the tablets was that of colloquial Latin, suggesting that most of the dedications had been made by members of the population with limited access to formal education, even in the case of practiced scribes. ${ }^{43}$ Tomlin hypothesizes that the majority of thefts would have occurred at the baths, and at the hands of bathhouse thieves (fures balnearii), hence the large number of outer garments and coins lost. ${ }^{44}$ This also suggests that the majority of supplications were from individuals of a lower social standing, the victim not being able to afford a slave

\footnotetext{
42 Tomlin 1988: 183-4, n. 54.

${ }^{43}$ See Adams 1992: 24. Note the correlation in literacy noted in the Vindolanda Tablets. See Adams 1995: $130-1$.

${ }^{44}$ Tomlin 1988: 80.
} 
of his own, or to even pay one to mind his belongings while in the baths. ${ }^{45}$ On the other hand, the loss may be due to careless and suspicious patrons of the baths misplacing such items, like rings, and instantly suspecting thieves. ${ }^{46}$ But despite this, there is another curse tablet that refers to a theft from their house (Tablet 99) and also the theft of a bronze vessel, where the thief is cursed to 'spill his own blood into the vessel itself' (Tablet 44). But the prevalence of bathing tunics and small numbers of coins would imply that after the discovery of a theft while at the baths, the making of such incantations on curse tablets may have been a convenient method of exacting revenge at the height of the victim's frustration.

The Uley tablets are of much the same nature as the tablets at Bath, except that the stolen articles are of more value, with mention of draught animals (Tablet $1),{ }^{47}$ gold rings (Tablet 3), cash from a strong box, sheep, and two wheels and a cow being stolen. ${ }^{48}$ These tablets also include accusations of embezzlement and, when combined with the different array of stolen articles, demonstrate the difference between the requests placed at an urban healing shrine, and a rural temple with a more restricted clientele. ${ }^{49}$ But despite this difference the nature of the curses themselves were quite similar, such as Tablet $4^{50}$ which reads:

\author{
Biccus dat M- \\ ercurio quidquid \\ pe(r)d(id)it si vir si m- \\ ascel ne meiat \\ ne cacet ne loqua- \\ tur ne dormiat \\ $n[e]$ vigilet nec s[a]- \\ [l]utem nec sa- \\ nitatem ne- \\ ss [i] in templo \\ Mercurii per- \\ tulerit ne co(n)- \\ scientiam de \\ pederat ness[i] \\ me interceden- \\ te
}

“Biccus gives Mercury whatever he has lost (that the thief), whether man or male (sic), may not urinate nor defecate nor speak nor sleep nor stay awake nor [have] well-being or health, unless he brings (it) in the temple of Mercury; nor gain consciousness (sic) of (it) unless with my intervention."

\footnotetext{
${ }^{45}$ Tomlin 1988: 81.

46 Tomlin 1988: 81.

${ }^{47}$ Woodward \& Leach 1993: 119-20, no. 1.

${ }^{48}$ Woodward \& Leach 1993: 116, 123, nos. 3, 72, 75.

49 Woodward \& Leach 1993: 116, no. 78.

${ }^{50}$ Woodward \& Leach 1993: 125, n. 4.
} 
Mercury was the patron deity at Uley, being combined with an unnamed Celtic deity, but there were also dedications to Mars and Mars Silvanus. ${ }^{51}$ As with the continental curse tablets and those at Bath, local deities were frequently called upon to exact revenge. The devotion here to Mercury is quite understandable, considering the prosperous, rural nature of the community. As well as being a protector of his patrons from the otherworld, the god was seen as a protector of herds and flocks, ${ }^{52}$ hence the requests for the return of cattle and sheep. ${ }^{53}$ Worship of Mercury, also the patron deity of trade and commerce, is significant in reflecting the attitude of the relatively wealthy Uley population. The affluence of the community is reflected in the petitions to the god, where the claims are of much greater value, with the greatest amount being of 100,000 denarii. ${ }^{54}$

Through an examination of Roman-British curse tablets, it is evident that they were definitely used by the lower social classes: owing to the small amounts of money mentioned at Bath, the lead tablets were obviously cheap to produce and inscribe, as suggested by Tomlin. ${ }^{55}$ The defixiones were not used purely by the lower classes, however, as they were also used by the upper classes when they felt that seeking supernatural justice was the only action available. Even though we do not have the names of many of the supplicants on the tablets, ${ }^{56}$ the high percentage of native names, and complete absence of Roman citizens ${ }^{57}$ reflect that this Roman custom was definitely appropriated by the native peasant community. ${ }^{58}$ The idea of directly petitioning the deities that surrounded them would surely have appealed to the ordinary Briton: if others, such as the Romans, could request divine assistance, it would be foolish to not make a request if one had been aggrieved. It must be noted however, that the British employed the practice in their own fashion, being particularly motivated by the desire for the recompense of theft. The language, it seems, was open for interpretation by the natives, possibly reflecting their own style, with such examples as the curse tablet discovered at Clothall revealing the break from Roman tradition: "Tacita, hereby accursed, is labelled old like putrid gore". ${ }^{9}$ Thus the Britons pursued their own method, not conforming exactly to Roman customs in their use of the tablets. For some Britons, curse tablets became a religious outlet to relieve their frustration in personal matters. ${ }^{60}$ Despite the Romanised aspirations of many dedicators at Uley, it would be impossible to deduce that the use of defixiones was due solely to Roman influence, in view of the selective ways in which the natives applied them. The locals certainly adopted the concept in their own fashion, harmonizing the Greco-Roman tradition within their own style of worship of native deities.

\footnotetext{
${ }^{51}$ Woodward \& Leach 1993: 115, 119, nos. 1, 2, 3.

52 Ross 1992: 205.

${ }^{53}$ Woodward \& Leach 1993: 126-7.

${ }^{54}$ Woodward \& Leach 1993: 130, n. 78.

55 Tomlin 1988: 80.

${ }^{56}$ Woodward \& Leach 1993: 117, 127, nos. 3, 7, 8, 12.

57 Tomlin 1988: 96.

${ }^{58}$ Hassall \& Tomlin 1993: 310, n. 2. A Defixio found at Ratcliffe-on-Soar exhibits two Celtic names, being Camulorix and Titocuna, appealing to an unknown mule deity. See Burnham, Keppie, Esmonde Cleary \& Tomlin 1993: 310-13.

${ }^{59}$ RIB 221.

60 Tomlin 1988: 101.
} 
When these curse tablets from Bath and Uley are compared with the other religious inscriptions from these temple complexes, there are several conclusions which can be drawn. Firstly, the material used is the most obvious difference, with the dedicatory altars discovered at both being quite large and monumental. ${ }^{61}$ This rather obvious difference highlights the emphasis that was placed upon display for these dedications, whereas the curse tablets were much smaller, rolled or folded and probably out of public view. It seems that the larger inscriptional dedications, such as altars, were intended to be viewed as much by the other devotees as by the presiding deity. This difference is probably indicative of the different perspectives from which the deity was approached by the individuals, with curse tablets having a particularly negative approach, as we have seen. This contrast did not preclude a person from using both methods; each style of supplication or request was simply utilized in the most appropriate circumstance, with either the fulfilment of a vow or a curse on an enemy.

Naturally the lower cost of production for the curse tablets made these more accessible to the lower strata of society, which is especially noticeable at the Bath complex. From this overview, however, it seems that the British technique of using curse tablets was quite different to that on the continent, but this can be explained. Even on the continent, it is common to discover several curse tablets dealing with one type of subject matter, such as the curses on athletes found near the Agora in Athens, the love incantations discovered together in Egypt and the curses on charioteers in Carthage. It shows that the location where the defixiones were deposited was an important consideration. Naturally it would appear logical for certain sanctuaries to inspire a consistent type of petition; requests which were appropriate for the traditional resident deity. Patterns of requests at the Bath and Uley complexes were also understandably consistent with more practical considerations concerning the types of patrons, comparing an urban healing shrine associated with hot springs to a wealthy rural temple where the clientele were probably local. But, this does not completely explain the preponderance of British curses about theft. Again, I think that this is simply the method by which the local populations adopted a foreign tradition to serve their own purposes.

In light of the question on ritual and magic, it seems to me that the deposition itself would have been just as important as the words inscribed on the tablets. Good examples of this from Bath are Tablets 2, 3 and 51, which simply provide a list of names without any obvious formulaic incantation. But it would be foolish to assume that there was no ritual associated with these curse tablets. It could be that the words may have been spoken while depositing the tablet or perhaps that by simply depositing it was enough to gain the attention of, in this case, Sulis-Minerva. The location was obviously also of great importance. Both the Bath and Uley complexes have evidence of Iron Age sanctity before the erection of the Romanised temples. In view of this, it may provide some explanation of the comparatively unique method of curse tablet composition in Britain.

Versnel has highlighted how the majority of defixiones in the Roman Imperial period were intended to either injure or constrain a person who was disliked by the author of the curse tablet, ${ }^{62}$ which is largely in keeping with the overly negative focus

${ }^{61}$ Cunliffe 1969: 189-90, n. 1.61, 1.62; RIB 143, 144; Woodward \& Leach 1993: 94-5.

62 Versnel 1991b: 191-2. 
of the continental cursing theme. On the continent the most common theme was to curse an individual in order to prevent them from acting or living in a certain fashion. Those who were cursed were bound to the will of the author in a largely preventative manner. This was not the case in the Romano-British defixiones. The overwhelming majority of curse tablets discovered at Bath and Uley were reactionary: an act or wrong had been done to the author and through the use of defixiones they sought to redress the matter.

The basic theme of Romano-British curse tablets was revenge, which was quite different in orientation to the continental 'precursor' model. Naturally there have been several instances of reactionary curses discovered on the continent, but they comprise a minority, which is in stark contrast to the high percentage of those discovered in Britain. In recent years there have actually been a large number of 'reactionary' curses discovered on the continent, which has changed the overall impression of continental curses somewhat. The most notable examples have been uncovered at the Magna Mater sanctuary in Mainz, ${ }^{63}$ which have predominantly dealt with theft. Several other curses have been discovered in modern Portugal and Spain that also follow the 'prayers for justice' format, ${ }^{64}$ which seem to be more akin with the Romano-British tradition rather than the prevalent continental model. These discoveries highlight the frequent regional basis upon which curse tablets and their use are interpreted and used by the various communities within the Roman Empire. While these discoveries are inherently significant they still seem to be exceptions to the overall tradition for composing curse tablets on the continent. Nevertheless, the almost exclusive model of using curse tablets in Roman Britain as 'prayers for justice' cannot be underestimated. The exclusivity of the Romano-British tradition may provide a more extreme example of regional interpretations of how to use curse tablets, which also occurred in other provincial regions of the Roman Empire where the defixiones tradition had been a comparatively recent introduction.

The strong prevalence for the reactive style of defixio in Roman Britain is not only shown through the finds from Bath and Uley, but also from elsewhere throughout the province. There have been other examples of defixiones that resulted from theft discovered elsewhere in Gloucestershire, ${ }^{65}$ Suffolk, ${ }^{66}$ Hertfordshire, ${ }^{67}$ and Norfolk. ${ }^{68}$ The revenge theme within Romano-British curse tablets is also clearly apparent in examples discovered in London, ${ }^{69}$ and also Wanborough in Wiltshire. ${ }^{70}$ When the broad geographical range of these is considered in association with the thematic consistency it is quite clear that Romano-British defixiones should be viewed in a different fashion to their continental counterparts. The basic premise behind all of these defixiones was the same [to seek the advantage of the author through the disadvantage of another person/group], but it was in their intentions that they were different. In accordance with the majority of magical incantations, according to the Frazerian model, the majority of continental defixiones seem to have been intended to

\footnotetext{
${ }^{63}$ Blänsdorf 2005; Witteyer 2004 and 2005.

${ }^{64}$ Faraone, Garnand \& Lopez-Ruiz 2005; Versnel 1994, 1998, 1999 and 2002.

${ }^{65}$ Frere \& Tomlin 1991: 293-5; Adams 2005: 69.

${ }^{66}$ Burnham, Keppie, Esmonde Cleary, Hassall \& Tomlin: 1994: 293-5

${ }^{67}$ Burnham, Keppie, Esmonde Cleary \& Tomlin 1997: 455-7.

${ }^{68}$ Burnham, Keppie, Esmonde Cleary, Hassall \& Tomlin 1994: 296-7.

${ }^{69}$ Frere, Hassall \& Tomlin 1987: 360-3.

${ }^{70}$ Hassall, Wilson, Wright \& Rea 1972: 363-7.
} 
attain individual goals that frequently countered the benefit of others. ${ }^{71}$ The reactionary theme of Romano-British curse tablets was quite different: they sought either 'justice' [from the perspective of the author] or revenge for a previous wrong, which suggests a completely different motive. This should not be taken as a suggestion that the Romano-British examples were morally 'superior', but more that the social contexts in which they were used [or provoked] was quite different to the examples of other curse tablets on the continent. The Romano-British examples were 'magical' reactions to an action rather than a provocation, and they were typically centred upon 'correcting' the status quo rather than delivering an advantage for the author. This attitude was also prevalent in some areas on the continent, but the exclusive use of curse tablets as 'prayers for justice' in Roman Britain provides a compelling and unprecedented example of a regional interpretative process.

Dr. Geoff W. Adams

Monash University, Australia

E-mail: Geoff.Adams@arts.monash.edu.au

\section{References}

Adams, G. W. (2005) Romano-Celtic Élites and their Religion: a study of archaeological sites in Gloucestershire. Armidale: Caeros.

Adams, J. N. (1992) 'British Latin: the text, interpretation and language of the bath curse tablets.' - Britannia 23, 1-26.

Adams, J. N. (1995) 'The language of the Vindolanda writing tablets: an interim report.' - JRS 85, 86-134.

Audollent, A. (1967) Defixionum tabellae. Frankfurt: Minerva. [Reprint of 1904 Paris edition.]

Blänsdorf, J. (2005) 'The curse tablets from the sanctuary of Isis and Magna Mater in Mainz.' - MHNH: Revista Internacional de Investigación sobre Magia y Astrología Antiguas 5, 11-26.

Burnham, B. C.; Keppie, L. J. F.; Esmonde Cleary, A. S.; Hassall, M. W. C.; Tomlin, R. S. O. (1994) 'Roman Britain in 1993.' - Britannia 25, 245-291, 293-314.

Burnham, B. C.; Keppie, L. J. F.; Esmonde Cleary, A. S.; Tomlin, R. S. O. (1993) 'Roman Britain in 1992.' - Britannia 24, 269-309.

Burnham, B. C.; Keppie, L. J. F.; Esmonde Cleary, A. S.; Tomlin, R. S. O. (1997) 'Roman Britain in 1996.' - Britannia 28, 395-453, 455-472.

Cunliffe, B. (1969) Roman Bath. London: The Society of Antiquaries of London.

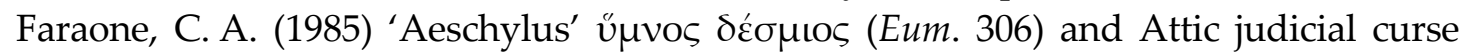
tablets.' - JHS 105, 150-154.

Faraone, C. A. (1991a) 'Binding and burying the forces of evil: the defensive use of 'voodoo dolls' in Ancient Greece.' - CA 10.2, 165-220.

Faraone, C. A. (1991b) 'The agonistic context of early Greek binding spells.' - Faraone, C. A.; Obbink, D. (eds.), Magika Hiera: Ancient Greek Magic and Religion. Oxford: Oxford University Press, 3-32.

\footnotetext{
${ }^{71}$ Versnel 1991b: 178-9.
} 
Faraone, C. A. (1996) 'Taking the "Nestor's Cup inscription" seriously: erotic magic and conditional curses in the earliest inscribed hexameters.' - CA 15.1, 77-112.

Faraone, C. A. (1999) 'Curses and social control in the law courts of classical Athens.' Dike 2, 99-121.

Faraone, C. A.; Garnand, B.; Lopez-Ruiz, C. (2005) 'Micah's mother (Judges 17:1-4) and a curse from Carthage (KAI 89): Evidence for the Semitic origin of Greek and Latin curses against thieves?' - Journal of Near Eastern Studies 64, 161-186.

Fowler, R. L. (1995) 'Greek magic, Greek religion.' - ICS 20, 1-22.

Frere, S. S.; Hassall, M. W. C.; Tomlin, R. S. O. (1987) 'Roman Britain in 1986.' Britannia 18, 301-377.

Frere, S. S.; Tomlin, R. S. O. (1991) 'Roman Britain in 1990.' - Britannia 22, 221-311.

Gordon, R. (1987) 'Aelian's Peony: the location of magic in Graeco-Roman tradition.' Comparative Criticism 9, 59-95.

Hassall, M. W. C.; Tomlin, R. S. O. (1986) 'Roman Britain in 1985: inscriptions.' Britannia 17, 428-454.

Hassall, M. W. C.; Tomlin, R. S. O. (1993) 'Roman Britain in 1992: inscriptions.' Britannia 24, 310-322.

Hassall, M. W. C.; Wilson, D. R.; Wright, R. P.; Rea, J. (1972) 'Roman Britain in 1971.' Britannia 3, 298-367.

Jordan, D. R. (1985a) 'A survey of Greek defixiones not included in the special corpora.' - GRBS 26, 151-197.

Jordan, D. R. (1985b) 'Defixiones from a well near the Southwest corner of the Athenian Agora.' - Hesperia 54.3, 205-255.

Jordan, D. R. (2000) 'New Greek Curse Tablets (1985-2000).' - GRBS 41, 5-46.

Reynolds, J. (1990) 'Review Articles: Gifts, Curses, Cult and Society.' - Britannia 21, 379-391.

RIB = Collingwood, R. G.; Wright, R. P. (1965) The Roman Inscriptions of Britain. Vol. I. Oxford: Clarendon Press.

Ross, A. (1992) Pagan Celtic Britain. London: Routledge.

Tomlin, R. S. O. (1988) Tabellae Sulis: Roman inscribed tablets of tin and lead from the sacred spring at Bath. Oxford: Oxford University Committee for Archaeology.

Versnel, H. S. (1985) 'May he not be able to sacrifice...: concerning a curious formula in Greek and Latin curses.' - ZPE 58, 247-269.

Versnel, H. S. (1991a) 'Beyond cursing: the appeal to justice in judicial prayers.' Faraone, C. A.; Obbink, D. (eds.), Magika Hiera: Ancient Greek Magic and Religion. Oxford: Oxford University Press, 60-106.

Versnel, H. S. (1991b) 'Some reflections on the relationship magic-religion.' - Numen 38.2, 177-197.

Versnel, H. S. (1994) 'Peprêmenos: The Cnidian Curse Tablets and Ordeals of Fire.' Hägg, R. (ed.), Ancient Greek Cult Practices from the Epigraphic Evidence: Proceedings of the Second International Seminar on Ancient Greek Cult. Stockholm: Astroms, 145-154.

Versnel, H. S. (1998) 'And any other part of the entire body there may be...: An Essay on Anatomical Curses.' - Graf, F. (ed.), Ansichten griechischer Rituale: GeburtstagsSymposium für Walter Burkert. Stuttgart: Teubner, 217-267.

Versnel, H. S. (1999) 'Punish those who rejoice in our misery: On Curse Tablets and Schadenfreude.' - Jordan, D. R. et al. (eds.), The World of Ancient Magic, Papers from the 
First International Samson Eitrem Seminar at the Norwegian Institute at Athens, 4-8 May, 1997. Bergen: Norwegian Institute at Athens, 125-162.

Versnel, H. S. (2002) 'Writing Mortals and Reading Gods: Appeal to the Gods as a Duel Strategy for Social Control.' - Cohen, D. (ed.), Demokratie, Recht und soziale Kontrolle im klassischen Athen. München: Oldenbourg, 37-76.

Witteyer, M. (2004) 'Verborgene Wünsche: Befunde antiken Schadenzaubers aus Mogontiacum-Mainz.' - Brodersen, K.; Kropp, A. (eds.), Fluchtafeln. Neue Funde und Deutungen zum antiken Schadenzauber. Frankfurt: Antike, 41-50.

Witteyer, M. (2005) 'Curse tablets and voodoo dolls from Mainz. The archaeological evidence for magical practices in the sanctuary of Isis and Magna Mater.' - MHNH: Revista Internacional de Investigación sobre Magia y Astrología Antiguas 5, 105-124.

Woodward, A.; Leach, P. (1993) The Uley Shrines. London: Routledge. 